\title{
The Relationship Between Aterosclerotic Cardiovascular Diseases and Drinking Water Hardness Level in Çanakkale Province
}

\author{
Çanakkale Ilinde Aterosklerotik Kardiyovasküler Hastalıkların Içme Suyu Sertlik \\ Seviyesi ile llișkisi \\ (D) Sonay OĞUZ
}

Çanakkale Onsekiz Mart University Faculty of Medicine, Department of Carvicascular Surgery, Çanakkale, Turkey

\begin{abstract}
Aim: Cardiovascular diseases (CVH) still maintain their leadership among causes of death. Many studies have been carried out on risk factors and the relationship of disease and their proven recommendations have entered current guidelines. However, it is seen that there are opposing interpretations in the literature regarding the relationship between water hardness and $\mathrm{CVH}$ and definite conclusions are still not reached. In Çanakkale province center, drinking water needs are met from two different sources with different hardness degrees. This may help to better understand the relationship between water hardness level and CVH. The study was designed for this purpose.

Materials and Methods: Patients with a diagnosis of atherosclerosis (coronary artery, carotid artery and peripheral artery disease), who applied to Çanakkale Onsekiz Mart University Training and Practice Hospital between 2015 and 2020, were retrospectively identified, and atherosclerotic group was formed. Corresponding to this group, a non-atherosclerotic (non-AS) group was formed by observing "propensity score matching" according to age, gender, arterial hypertension (HT), diabetes mellitus (DM), and presence of dyslipidemia (DL). The pH, hardness, calcium, magnesium values of the last five years were determined from the city center drinking water analyses taken from local governments and were associated with the address. Using this information, cases consuming water of different hardness were determined. Statistically, the significance of the water hardness values between the two groups was evaluated.

Results: There was no significant difference in age, gender, arterial HT, DM, DL between the groups ( $p>0.05$ ), and very high hardness water consumption was found significantly higher in the non-AS group $(\mathrm{p}<0.001)$.

Conclusion: The results show that there may be an inverse relationship between the hardness level of drinking water and atherosclerosis. We strongly recommend that the results should be supported by field studies in appropriate locations and the public should be made aware of drinking water according to the results to obtain high scientific data.
\end{abstract}

Keywords: Cardiovascular diseases, drink water hardness, prevention

ÖZ

Amaç: Kardiyovasküler hastalıklar (KVH) ölüm sebepleri içerisindeki liderliğini halen korumaktadır. Risk faktörleri ve hastalık ilişkisi ile ilgili pek çok çalışma yapılmış ve ispatlanan öneriler güncel kılavuzlara girmiştir. Fakat su sertliği ve KVH ilişkisi ile ilgili literatürde karşıt yorumların olduğu ve halen kesin kanaatlere varılamadığı görülmektedir. Çanakkale şehir merkezinde içme suyu ihtiyacı sertlik derecesi farklı iki ayrı kaynaktan karşılanmaktadır. Bu durum su sertlik seviyesi ve KVH ilişkisinin daha iyi anlaşılmasına yardımcı olabilir. Bu amaçla çalışma planlanmıştır.

Gereç ve Yöntem: 2015-2020 yılları arasında Çanakkale Onsekiz Mart Üniversitesi Eğitim ve Uygulama Hastanesi'ne başvurmuş ateroskleroz ile ilişkili tanısı olan (koroner arter, karotis arter ve periferik arter hastalığı) Çanakkale il merkezine kayıtlı olgular retrospektif olarak tespit edilerek aterosklerotik (AS) grup oluşturuldu. Bu gruba karşılık gelecek şekilde olguların yaş, cinsiyet, arteriyel hipertansiyon (HT), diabetes mellitus (DM), dislipidemi (DL) mevcut olması durumuna göre, "propencity score matching" gözetilerek non-AS grup oluşturuldu. Yerel yönetimlerden elde edilen il merkezi içme suyu analizlerinden pH, sertlik, kalsiyum, magnezyumun son beş yıllık değerleri tespit edilip adres ile ilişkilendirildi. Bu bilgiler kullanılarak farklı sertlikte su tüketen olgular tespit edildi. İstatistiki olarak iki grup arasındaki su sertlik değeri açısından anlamlılık değerlendirildi.

Address for Correspondence: Sonay OĞUZ MD, Çanakkale Onsekiz Mart University Faculty of Medicine, Department of Carvicascular Surgery, Çanakkale, Turkey Phone: +90 2862635950 E-mail: soguz@ @ comu.edu.tr ORCID ID: orcid.org/0000-0002-4274-3828

Received: 25.11.2020 Accepted: 10.01.2021

๑Copyright 2021 by the Tekirdağ Namık Kemal University Faculty of Medicine / Namık Kemal Medical Journal published by Galenos Publishing House. 


\section{ÖZ}

Bulgular: Gruplar arasında yaş, cinsiyet, HT, DM, DL'de anlamlı farklılık yoktu (p>0,05), non-AS grubunda çok yüksek sertlikte su tüketiminin anlamlı seviyede yüksek olduğu tespit edildi $(p<0,001)$.

Sonuç: Elde edilen sonuçlar içme suyunun sertlik seviyesi ile ateroskleroz arasında ters bir ilişki olabileceğini göstermektedir. Bilimsel değeri yüksek veriler elde etmek için uygun lokasyonlarda saha çalışmaları ile sonuçların desteklenmesi ve çıkan sonuçlara göre halkın içme suyu konusunda bilinçlendirilmesi gerektiğini şiddetle tavsiye ediyoruz.

Anahtar Kelimeler: Kardiyovasküler hastalıklar, içme suyu sertliği, önlem

\section{INTRODUCTION}

In the world, cardiovascular system diseases are common in society and are the leading cause of death'. Many studies have tried to find the effects of environmental factors by examining their relationship with death and risk factors. The fact that life depends on water and water is essential for the body gives water special importance. The effects of drinking water on health have been shown in many studies and the importance of drinking water quality has been emphasized ${ }^{2-4}$. However, different results were found in existing studies on the relationship between drinking water hardness level and cardiovascular diseases (CVH). While there is a consensus on the positive effect between the magnesium level and $\mathrm{CVH}^{5-}$ ${ }^{8}$, there is no consensus on the hardness level of the water. While some studies have shown a positive effect between water hardness level and $\mathrm{CVH}^{9-13}$, some studies have shown that there is no relationship ${ }^{14-16}$. This issue is important for common $\mathrm{CVH}$ and it is still unclear, which suggests that it needs to be studied.

Çanakkale city center drink water is provided from two sources of different hardness (Table 1). The hardness levels of these spring waters are quite different from each other (Table 2). Different levels of water hardness used among the population with the same geographical, climatic and environmental conditions may be a suitable situation to show the relationship with $\mathrm{CVH}$. The study was organized for this purpose.

\section{MATERIALS AND METHODS}

Patients who applied to Çanakkale Onsekiz Mart University Training and Practice Hospital between 2015 and 2020 and who were diagnosed with atherosclerotic diseases (coronary artery, carotid artery and peripheral artery disease) were retrospectively identified and atherosclerotic (AS) group was created. Corresponding to this group, non-atherosclerotic (non-AS) group was created by taking into consideration the "propensity risk score matching" according to age, gender, arterial hypertension (HT), diabetes mellitus (DM), and dyslipidemia (DL). The average and change values of $\mathrm{pH}$, hardness, calcium, and magnesium for the last five years were determined from the city center drinking water supply (WS) analyses obtained from the local municipality and they were associated with the address. Using this information, cases consuming high hardness and very high hardness water were determined. Statistical significance between atherosclerotic $\mathrm{CVH}$ and water hardness was evaluated.

\section{Data Processing}

Hospital entries for the years of 2015-2020 were identified and filtered using Excel (Microsoft ${ }^{\circledR}$ Office 2016, Santa Rossa, California) program. Address records outside the Çanakkale city center were eliminated and only the target population registered in the city center was obtained (Figure 1). Arterial HT, DM, and DL cases diagnosed with International Classification of Disease-10 (ICD-10) codes were associated with the identification number. Age, gender, and address information were preserved. The ICD diagnosis codes (coronary artery disease, carotid artery disease, peripheral vascular disease groups) associated with the diagnosis of atherosclerotic disease were scanned and determined as the AS group. According to the data obtained from the local municipality, the address records were associated with the areas with very hard (source 1) and hard (source 2) drinking water ${ }^{17}$.

\section{Propensity Score Matching}

By Excel filtering method and applying "propensity score matching" process according to age, gender, HT, DM, and DL criteria, the non-AS group was created equivalent to the AS group, from the target population (the target population after the records with AS are removed) (Figure 2).

\section{Statistical Analysis}

Results were analyzed by SPSS (version 23.0, IBM, Chicago, IL). Continuous variables and categorical variables were expressed as mean with standard deviation and number with percentage, respectively. Groups were compared according to sample size using the Mann-Whitney $U$ test. Differences were considered significant when the $p$-value was less than 0.05 .

The study was approved by the Local Ethics Committee of Çanakkale Onsekiz Mart University (2011-KAEK27/2020-E.2000096163 approval date/number: 11.11.2020 / 13-01). 


\section{RESULTS}

A total of 1,908,049 hospital admissions were detected in 20152020. Records with addresses outside Çanakkale $(494,561)$ and villages $(37,150)$ were eliminated. Records with 433,047 addresses in the city center were obtained. Of these records, 93,298 were registered in very hard drinking water (source 1) region, 339,749 in hard drinking water (source 2) region. Entries under the same duplicate ID number have been reduced to a single record. The target population was determined by decreasing 494,561 records to 112,234 (Figure 1).

Table 1 shows the water analysis reports. The water hardness, magnesium and calcium values of water resources are different and the $\mathrm{pH}$ value is similar (Table 1).

Of the target population, 26,248 were registered in source 1 (very high water hardness), 85,986 in source 2 (high water hardness). 10,636 HT, 12,011 DM, 3,860 DL diagnosed records were detected. There were 6,726 records in the AS group and 6,726 in the non-AS group. In both groups (AS and non-AS), age of 61 years (range 16-95 years), HT 1,849, DM 650, DL 1,296, HT + DM 200, HT + DL 92, DM + DL 193, HT + DM + DL 68 recordings were detected. In the AS group, 3,826 male $(43.1 \%)$ and 2899 female (56.9\%); In the non-AS group, 3,822 (43.1\%) male and 2,903 (59.9\%) female records were detected.

There was no difference in age, gender, HT, DM, and DL between the groups ( $p>0.05)$, very high hardness water consumption was found significantly higher in the non-AS group $(p<0.001)$ (Table 3).

\section{DISCUSSION}

The relationship between drinking water hardness level and $\mathrm{CVH}$ is still unclear ${ }^{6,18}$. Çanakkale province center can provide information that will help enlighten this issue due to its mentioned characteristics in terms of drinking water resources. In the study model we designed, single-center patient records

\section{Table 1. Analysis results of drinking water resources}

\begin{tabular}{|l|l|l|l|l|l|}
\hline & $\mathbf{p H}$ & $\begin{array}{l}\text { Hardness } \\
\text { (French } \\
\text { hardness) }\end{array}$ & $\begin{array}{l}\text { Calcium } \\
\text { (mg/L) }\end{array}$ & $\begin{array}{l}\text { Magnesium } \\
\text { (mg/L) }\end{array}$ & $\begin{array}{l}\text { Consuming } \\
\text { population } \\
\text { (person) }\end{array}$ \\
\hline $\begin{array}{l}\text { Water } \\
\text { source 1 }\end{array}$ & 7,67 & 52,80 & 64,20 & 88,48 & 26,248 \\
\hline $\begin{array}{l}\text { Water } \\
\text { source 2 }\end{array}$ & 7,65 & 18,62 & 48,12 & 12,38 & 85,986 \\
\hline
\end{tabular}

Table 2. Water hardness classification 17

\begin{tabular}{|l|l|}
\hline French hardness & Degree of hardness \\
\hline $0-7,5$ & Soft \\
\hline $7,5-15$ & Medium hard \\
\hline $15-30$ & Hard \\
\hline 30 above & Very hard \\
\hline
\end{tabular}

were used. The weak points of the study are that the individuals in the target population can contact another health center, population mobility, the use of carboys, water purifiers instead of mains water and the data that cannot be collected about other risk factors (smoking, obesity, insufficient physical activity, genetic factors, etc.).

The scientific significance of the data obtained would weak results due to these missing data points. For this reason, we used the "propensity score matching" method in the model we created to strengthen the scientific significance. Results were obtained by equating all identified risk factors (age, gender, HT, DM, DL) in two groups, which might be associated with the disease. However, it must be admitted that the field and cohort studies related to the subject will produce more scientifically meaningful results, but the high number of data collection, Çanakkale drinking water features, may have the potential to generate information that will help in this regard. For this purpose, the data were collected and processed precisely. There was no significant difference between AS and non-AS groups in age, gender, HT, DM, and DL variables ( $p>0.05$ ). This was an expected result because the propensity score matching was done. There was a significant difference in WS $(p<0.001)$. Within the groups, the AS ratio was lower in source 1 , which had a very high water hardness ratio and

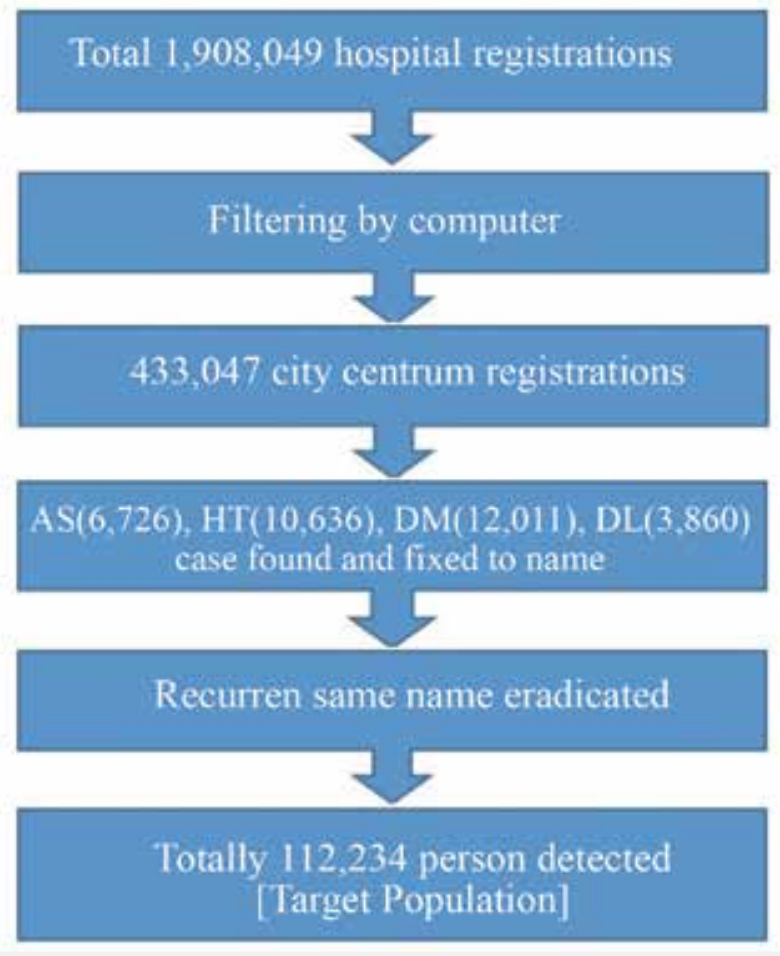

Figure 1. Data process algorithm

AS: Atherosclerotic group, HT: Hypertension, DM: Diabetes mellitus, DL: Dyslipidemia 
it was statistically significant. Another notable point was the difference in magnesium value between the two sources (source 1: $88.48 \mathrm{mg} / \mathrm{dL}$, source 2: $12.48 \mathrm{mg} / \mathrm{dL}$ ). Magnesium's cardioprotective effect has been shown in studies ${ }^{5-8}$. In our study, we could not show whether the low atherosclerosis rate in source 1 was caused by the difference in magnesium level or by the relationship with the hardness. However, it is known that the two most important factors in forming water hardness are the calcium and magnesium level it contains ${ }^{19,20}$. The water hardness relationship in source 1 is a situation that may be associated with high magnesium. In addition, there was a difference in calcium levels, too (source 1: $64.20 \mathrm{mg} / \mathrm{dL}$, source 2: $48.12 \mathrm{mg} / \mathrm{dL}$ ). However, this difference was not as much as the magnesium level. These are two important values that make up the water hardness level. In many studies, it has been shown that there is an inverse correlation between water hardness level and $\mathrm{CVH}$, in other words, $\mathrm{CVH}$ rate decreases with the consumption of high drinking water hardness ${ }^{9-13}$. We found similar results in our study. We even found that there was a difference between hard and very hard drinking water. Lacey and Shaper ${ }^{21}$ stated the positive effect up to $170 \mathrm{mg} / \mathrm{L}$ water hardness level in their study. In our study, we showed that the effect continued at much higher than this level (186.2/586 mg/L).

Different hypotheses have been proposed to explain the possible inverse relationship. However, none has been enough substantiated, nor has a distinct component been found to be conclusively linked with the $\mathrm{CVH}$. It may be correlated with

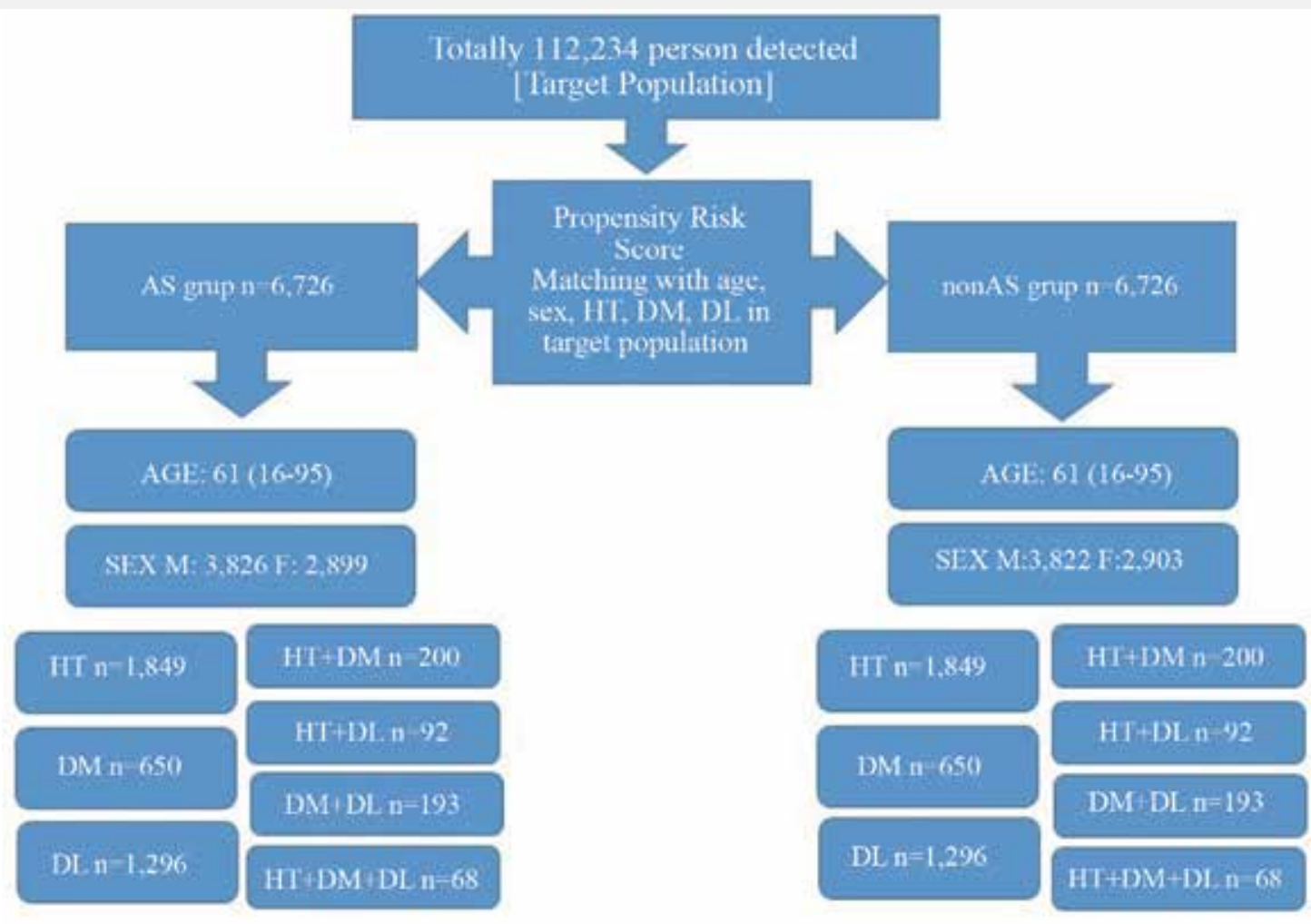

Figure 2. Propensity score matching algorithm and obtained data

AS: Atherosclerotic group, Non-AS: non-Atheroclerotic group, HT: Hypertension, DM: Diabetes mellitus, DL: Dyslipidemia, WS: Water supply, F: Female, M: Male

Table 3. Distribution of variables in groups and statistics

\begin{tabular}{|c|c|c|c|c|c|c|c|c|}
\hline & \multirow{2}{*}{ Age (years) } & \multirow{2}{*}{\multicolumn{2}{|c|}{ Gender }} & \multirow{3}{*}{$\begin{array}{l}\text { HT } \\
1.849\end{array}$} & \multirow{3}{*}{$\begin{array}{l}\text { DM } \\
650\end{array}$} & \multirow{3}{*}{\begin{tabular}{|l|} 
DL \\
1.296 \\
\end{tabular}} & \multicolumn{2}{|c|}{ WS } \\
\hline & & & & & & & \multirow{2}{*}{$\begin{array}{l}\text { Hard (2) } \\
5.118(76.2 \%)\end{array}$} & \multirow{2}{*}{$\begin{array}{l}\text { Very hard (1) } \\
1.607(23.8 \%)\end{array}$} \\
\hline AS & 61 (16-95) & F: $43.1 \%$ & M: 56.9\% & & & & & \\
\hline Non-AS & 61 (16-95) & F: $43.1 \%$ & M: 56.9\% & 1.849 & 650 & 1.296 & $4.585(68.1 \%)$ & $2.140(31.9 \%)$ \\
\hline$P$ value & 0.996 & \multicolumn{2}{|c|}{0.944} & 1.000 & 1.000 & 1.000 & \multicolumn{2}{|c|}{$<0.001$} \\
\hline
\end{tabular}


high magnesium level in hard water, which has some antistress impacts against coronary heart disease. Magnesium is an enzyme ( $\mathrm{Na}+/ \mathrm{K}+$ ATPase) activator and regulates cellular energy metabolism, vascular tone, and the cell membrane ion transport. A lack of magnesium causes a reduction in the concentration of intracellular potassium and an increase in calcium levels. Magnesium deficiency may rise the contractility of blood vessels. Magnesium causes vasodilation by the stimulation of endothelial prostacyclin release and prevents vasoconstriction $^{6}$.

However, contrary to these studies, studies show that there is no relationship ${ }^{14-16}$ and additionally, there are studies showing an increase in $\mathrm{CVH}$ as water hardness decreases ${ }^{5,22}$.

This interaction is extremely important for this disease group, which is one of the most common causes of death. However, definitive interpretations are still not possible and meta-analysis suggests that further studies are required ${ }^{6,18}$. In addition, studies report positive effects on growth retardation, reproductive failure, gastrointestinal diseases, cancers $^{23-27}$ and diabetes ${ }^{28}$. When the available information on the water hardness level is examined, it is concluded that it should be seriously emphasized and considered. In addition, the contamination of drinking water, storage, transportation and heavy metal toxic containment have a separate relationship with the disease. Society may tend to consume soft hardness drinking water. Even people that are exposed to very high hardness water consumption (source 1) in Çanakkale are complaining about this and the local municipality is looking for alternative solutions to soften the water.

\section{Study Limitations}

The weak points of the study are that the individuals in the target population can contact another health center, population mobility, the use of carboys, water purifiers instead of mains water and the data that cannot be collected about other risk factors (smoking, obesity, insufficient physical activity, genetic factors, etc.).

\section{CONCLUSION}

The results of the studies on water hardness show the importance and necessity of further studies to solve the relationship between drinking water and disease in terms of public health. Our study results show that there may be an inverse relationship between the hardness level of drinking water and atherosclerosis. We believe that, to obtain high scientific data, it is necessary to support the results with field studies in appropriate locations and to raise the awareness of the public about drinking water according to the results. We strongly recommend that this issue also should be emphasized such as high blood pressure, smoking, obesity, diabetes, high cholesterol and similar risk factors.

\section{Acknowledgments}

I would like to thank Çanakkale and Kepez municipalities and laboratory staff who precisely organized the water analysis results required for the study, and Assoc. Prof. Dr. H. Fatih Aşgün for help with prepencity risk scoring.

\section{Ethics}

Ethics Committee Approval: The study was approved by the Local Ethics Committee of Çanakkale Onsekiz Mart University (2011-KAEK-27/2020-E.2000096163 approval date/number: 11.11.2020/13-01).

Informed Consent: Retrospective study.

Peer-review: Externally peer-reviewed.

Financial Disclosure: The author declared that this study received no financial support.

\section{References}

1. Barquera $S$, Pedroza-Tobias A, Medina $C$, Hernández-Barrera L, BibbinsDomingo K, Lozano R, et al. Global Overview of the Epidemiology of Atherosclerotic Cardiovascular Disease. Arch Med Res. 2015;46:328-38.

2. Pal $M$, Ayele $Y$, Hadush $M$, Panigrahi $S$, Jadhav VJ. Public health hazards due to unsafe drinking water. Air Water Borne Dis. 2018;7:1-6.

3. Lazzari A, De Waure C, Azzopardi-Maskat N. Health in all policies. In A systematic review of key issues in public health. Springer: Cham; 2015. p. 277-86.

4. Chouhan B, Meena P, Poonar N. Effect of heavy metal ions in water on human health. Int J Sci Eng Res. 2016;4:2015-7.

5. Anderson TW, Neri LC, Schreiber GB, Talbot FD, Zdrojewski A. Letter: Ischemic heart disease, water hardness and myocardial magnesium. Can Med Assoc J. 1975;113:199-203.

6. Sengupta P. Potential health impacts of hard water. Int J Prev Med. 2013:4:866-75.

7. Rubenowitz $E$, Axelsson G, Rylander R. Magnesium in drinking water and death from acute myocardial infarction. Am J Epidemiol. 1996;143:456-62.

8. Yousefi $M$, Najafi Saleh $H$, Yaseri $M$, Jalilzadeh $M$, Mohammadi AA Association of consumption of excess hard water, body mass index and waist circumference with risk of hypertension in individuals living in hard and soft water areas. Environ Geochem Health. 2019;41:1213-21.

9. Leoni V, Fabiani L, Ticchiarelli L. Water hardness and cardiovascular mortality rate in Abruzzo, Italy. Arch Environ Health. 1985;40:274-8.

10. Yang CY, Chiu HF, Chiu JF, Wang TN, Cheng MF. Magnesium and calcium in drinking water and cerebrovascular mortality in Taiwan. Magnes Res. 1997;10:51-7.

11. Pocock SJ, Shaper AG, Cook DG, Packham RF, Lacey RF, Powell P, et al. British Regional Heart Study: geographic variations in cardiovascular mortality, and the role of water quality. Br Med J. 1980;280:1243-9.

12. Nerbrand C, Svärdsudd K, Ek J, Tibblin G. Cardiovascular mortality and morbidity in seven counties in Sweden in relation to water hardness and geological settings. The project: myocardial infarction in mid-Sweden. Eur Heart J. 1992;13:721-7.

13. Yang $\mathrm{CY}$. Calcium and magnesium in drinking water and risk of death from cerebrovascular disease. Stroke. 1998;29:411-4. 
14. Mackinnon AU, Taylor SH. Relationship between 'sudden' coronary deaths and drinking water hardness in five Yorkshire cities and towns. Int J Epidemiol. 1980;9:247-9.

15. Sonneborn M, Mandelkow J, Schon D, Hoffmeister H, Zoeteman BCJ. Health effects of inorganic drinking water constituents, including hardness, iodide and fluoride. CRC Crit Rev Environ Control. 1983;13:1-22.

16. Meyers DH, Williams $G$. Mortality from all causes, and from ischaemic heart disease, in the Australian capital cities. Med J Aust. 1977;2:504-5.

17. Boysan F, Sengörür B. Su Sertliginin İnsan Sagligi Iç̧in Önemi. Sakarya Universitesi Fen Bil Ens Derg. 2009;13:7-10.

18. Sauvant MP, Pepin D. Drinking water and cardiovascular disease. Food Chem Toxicol. 2002;40:1311-25.

19. Cleveland TC. "The Drinking Water Dictionary" American Water Works Association. McGraw-Hill Education - Europe;2000.p.195.

20. Benjamin MM. Water Chemistry. 1 st ed. McGraw-Hill Companies; 2002.p.16-7.

21. Lacey RF, Shaper AG. Changes in water hardness and cardiovascular death rates. Int J Epidemiol. 1984;13:18-24.
22. Masironi R, Pisa Z, Clayton D. Myocardial infarction and water hardness in the WHO myocardial infarction registry network. Bull World Health Organ. $1979 ; 57: 291-9$.

23. Kuriki K, Tajima K. The increasing incidence of colorectal cancer and the preventive strategy in Japan. Asian Pac J Cancer Prev. 2006;7:495-501.

24. Hara N, Sakata K, Nagai M, Fujita Y, Hashimoto T, Yanagawa H. Statistical analyses on the pattern of food consumption and digestive-tract cancers in Japan. Nutr Cancer. 1984;6:220-8.

25. Ghadirian $P$, Thouez JP, PetitClerc $C$. International comparisons of nutrition and mortality from pancreatic cancer. Cancer Detect Prev. 1991;15:357-62.

26. Larsson SC, Bergkvist L, Wolk A. Milk and lactose intakes and ovarian cancer risk in the Swedish Mammography Cohort. Am J Clin Nutr. 2004;80:1353-7.

27. Thouez JP, Ghadirian P, Petitclerc C, Hamelin P. International comparisons of nutrition and mortality from cancers of the oesophagus, stomach and pancreas. Geogr Med. 1990;20:39-50.

28. Lopez-Ridaura R, Willett WC, Rimm EB, Liu S, Stampfer MJ, Manson JE, et al. Magnesium intake and risk of type 2 diabetes in men and women. Diabetes Care. 2004;27:134-40. 